\title{
Description of two new species from the genera Stertinius Simon, 1890 and Uroballus Simon, 1902 (Aranei: Salticidae) from north Borneo
}

\author{
Описание авух новых видов из родов Stertinius Simon, 1890 \\ и Uroballus Simon, 1902 (Aranei: Salticidae) с северного Борнео
}

\author{
Dmitri V. Logunov \\ Амитрий В. Аогунов
}

The Manchester Museum, University of Manchester, Oxford Road, Manchester M13 9PL, UK. E-mail: dmitri.v.logunov@manchester.ac.uk

KEY WORDS: Arachnida, Araneae, jumping spiders, Malaysia.

КЛЮЧЕВЫЕ СЛОВА: Arachnida, Araneae, пауки-скакунчики, Малайзия.

ABSTRACT. Two new species, Stertinius borneensis sp.n. (+) and Uroballus kinabalu sp.n. (+), from Malaysia (north Borneo) are diagnosed, illustrated and described. Their collecting locality is mapped.

How to cite this article: Logunov D.V. 2018. Description of two new species from the genera Stertinius Simon, 1890 and Uroballus Simon, 1902 (Aranei: Salticidae) from north Borneo // Arthropoda Selecta. Vol.27. No.1. P.57-60. doi: 10.15298/arthsel. 27.1.08

РЕЗЮМЕ. Описаны, диагностированы и иллюстрированы два новых вида из Малайзии (северный Борнео): Stertinius borneensis sp.n. (†) и Uroballus kinabalu sp.n. (+). Точка находки этих видов показана на карте.

\section{Introduction}

The small Oriental fissidentate salticid genera Stertinius Simon, 1890 (13 described species [WSC, 2017]) and Uroballus Simon, 1902 (four species [WSC, 2017]) seem to be related. Simon [1903] placed them in the group Simaethinae, together with eight other genera. Most of these genera, including Stertinius and Uroballus, are still grouped together by contemporary authors [e.g., Maddison, 2015]. Both genera are poorly studied and in need of revision, with the majority of their species, including the generotypes, being known from the original descriptions and from the type localities only. The main diagnostic characters between Stertinius and Uroballus (cf. Figs 5, 7) seem to be the position of PMEs (about half way between the ALEs and PLEs in Uroballus and markedly closer to the ALEs in Stertinius) and the presence of conspicuous and sclerotized sigillae in Stertinius, which are absent from Uroballus. The aim of the present paper is to describe two new species of Stertinius and Uroballus collected by night fogging from tree canopies in North Borneo.

The studied specimens were borrowed from the
Department of Invertebrates, Naturalis Biodiversity Center, Leiden, The Netherlands (NBCL; curator: Karen van Dorp). Abbreviations used in the text and figures are as follows: Eyes: AME - anterior median eye, ALE - anterior lateral eye, PME - posterior median eye, PLE - posterior lateral eye. Leg segments: Fm femur, $\mathrm{Pt}$ - patella, $\mathrm{Tb}$ - tibia, Mt - metatarsus, $\mathrm{Tr}$ tarsus. Position of leg spines: ap — apical, pr - prolateral, v - ventral. For the leg spination the system adopted is that used by Ono [1988]. The sequence of leg segments in measurement data is as follows: femur + patella + tibia + metatarsus + tarsus (total). All measurements are in $\mathrm{mm}$.

\section{Descriptions}

\section{Stertinius borneensis sp.n.}

Figs 1-5, Map.

TYPE: Holotype + (NBCL, RNMH.ARA.17921) from [Malaysia, Sabah], North Borneo, Mt. Kinabalu N[ational] P[ark], Poring Hot Springs $\left(6^{\circ} 2^{\prime} \mathrm{N}, 116^{\circ} 50^{\prime} \mathrm{E}\right), 500-700 \mathrm{~m}$ a.s.l., primary forest, canopy Aporusa sp. (Euphorbiacea), loc. 2, night fogging, 26.02. 1996, A. Floren. Ex. coll. C.L. Deeleman-Reinhold.

ETYMOLOGY. The specific epithet is a reference to Borneo, the largest island in SE Asia, where the type locality of the new species (Mt. Kinabalu N.P.) is situated.

DIAGNOSIS. Of the properly illustrated Stertinius species, the new species is closest to $S$. niger Merian, 1911 (cf. figs 24-26 in Logunov et al. [1997]) from which the female can be distinguished by the shorter insemination ducts and the different relative size and conformation of spermathecal chambers (Figs 2, 3).

DESCRIPTION. Male unknown.

FEMALE. Measurements. Carapace 1.63 long, 1.38 wide and 0.63 high at PLE. Ocular area 1.00 long, 1.05 wide anteriorly and 1.40 wide posteriorly. Diameter of AME 0.31. Clypeus not marked, chelicera length 0.34. Abdomen 2.00 long, 1.34 wide. Length of leg seg- 


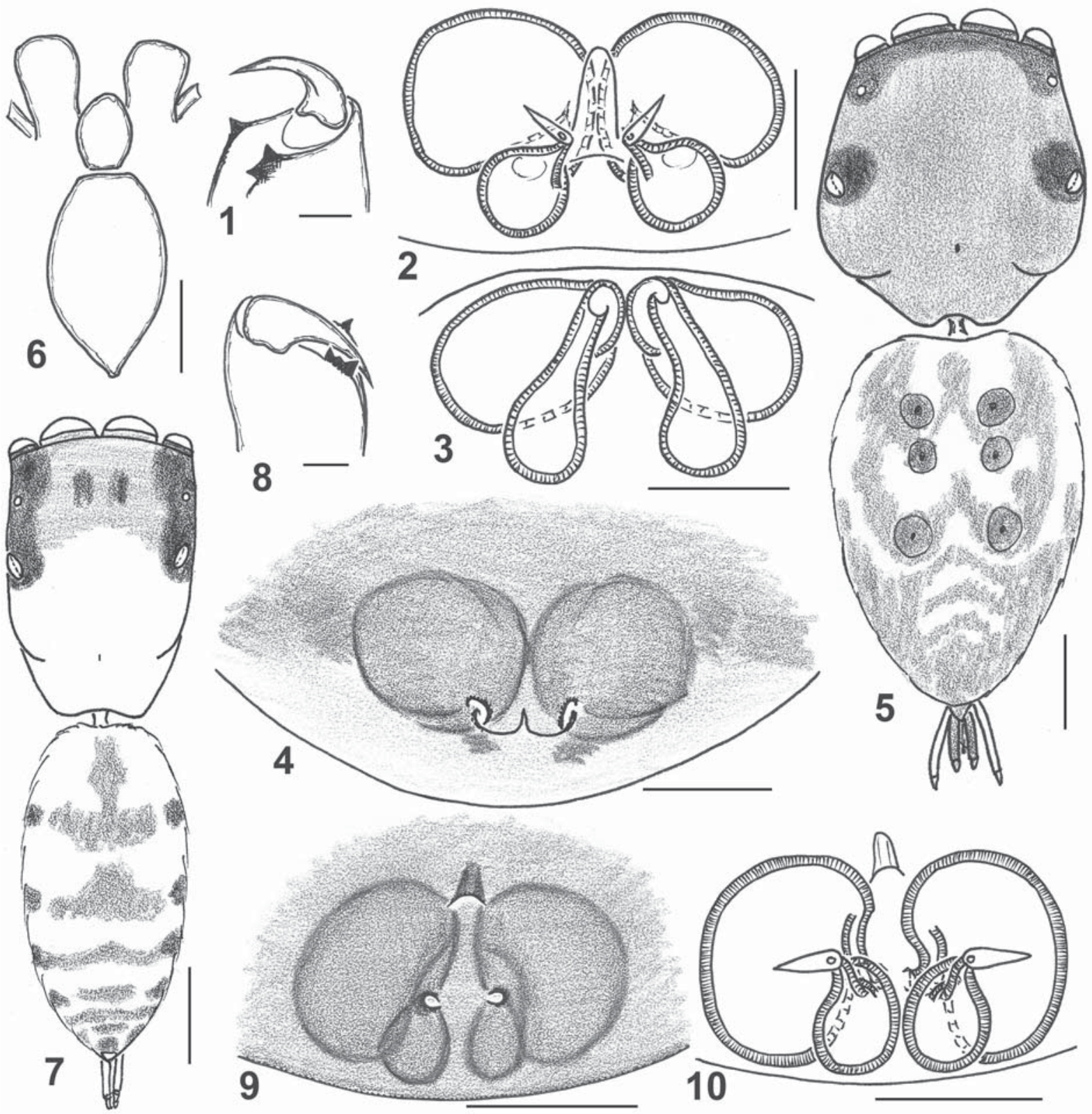

Figs 1-10. Copulatory organs and somatic characters of the holotype females of Stertinius borneensis sp.n. (1-5) and Uroballus kinabalu sp.n. (6-10): 1, 8 - chelicerae, ventral view; 2, 10 - spermathecae, dorsal view; 3 - ditto, rear view; 4, 9 - epigyne, ventral view; 6 - sternum, labium and endites, ventral view; 5,7 - general appearance, dorsal view. Scale bars: $(1-4,8-10) 0.1 \mathrm{~mm}$, (6) 0.25 $\mathrm{mm},(5,7) 0.5 \mathrm{~mm}$.

Рис. 1-10. Копулятивные органя и соматические признаки самок-голотипов Stertinius borneensis sp.n. (1-5) и Uroballus kinabalu sp.n. (6-10): 1, 8 - хелицеры, вид снизу; 2, 10 - сперматеки, вид сверху; 3 - тоже, вид сзади; 4, 9 - эпигина, вид сверху; 6 - стернум, лабиум и эндиты, вид снизу; 5,7 - общий вид, сверху. Масштаб: $(1-4,8-10) 0,1$ мм, (6) 0,25 мм, $(5,7) 0,5$ мм.

ments: I: $0.88+0.38+0.50+0.45+0.30(2.51) ; \mathrm{II}:$ $0.60+0.45+0.35+0.31+0.28(1.99) ;$ III: $0.63+$ $0.30+0.30+0.33+0.28(1.84) ; \mathrm{IV}: 0.85+0.38+$ $0.46+0.40+0.28$ (2.37). Leg formula: I,IV,II,III. Leg spination. Leg I: Fm pr 1ap, Tb v 1-2-2ap, Mt v 2-2ap. Leg II: Fm d 0-1-1-1, remaining segments are spineless. Leg III: Fm d 0-1-1, remaining segments are spineless. Leg IV: Fm d 0-1-2, Tb v 2ap, Mt pr and v 1ap.
Coloration (in alcohol). Carapace russet, its surface shagreen, sparsely covered with white recumbent scales forming a dense white fringe above the eyes of the first row; black around eyes; fovea is small and poorly visible. Clypeus is not marked. Sternum, endites, labium and chelicerae russet. Abdomen: dorsum light yellow (almost white), with three pairs of large, sclerotized sigillae and a reticulate pattern of brownish grey 


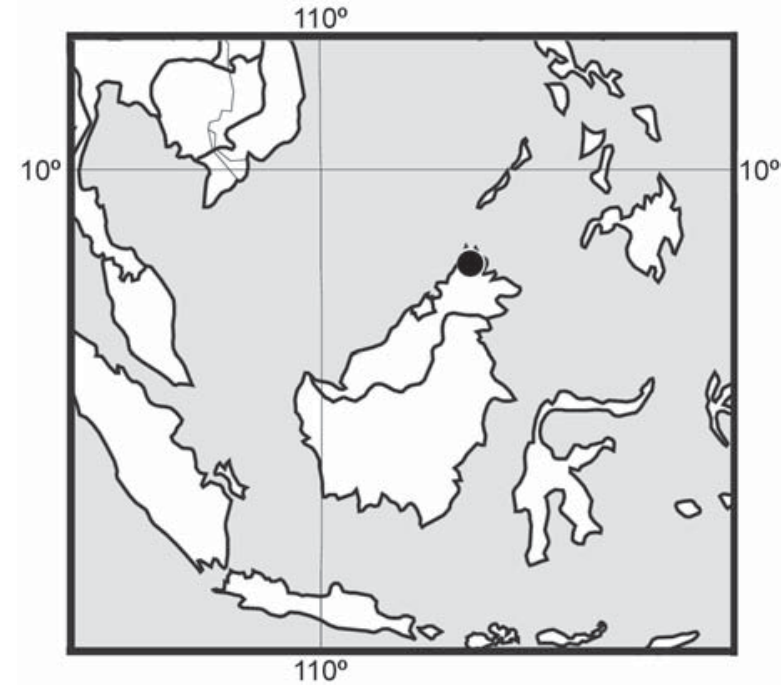

Map. The collecting locality of Stertinius borneensis sp.n. and Uroballus kinabalu sp.n.

Карта. Точка находок Stertinius borneensis sp.n. и Uroballus kinabalu sp.n.

stripes and patches (Fig. 5); sides light yellow (almost white), with a rear third grey; venter light yellow (almost white), with three longitudinal brownish grey stripes. Book lung covers light yellow (almost white). Spinnerets long: dorsal pair light yellow (almost white), others brownish grey. Legs I strongest and thickest, with swollen femora, yellowish orange, but their patella yellow. Legs II-IV light yellow (almost white), with brownish (semi)rings on segment joints. Palps light yellow, with a dense fringe of light yellow hairs on median-dorsal sides of their tarsi. Epigyne and spermathecae as in Figs 2-4: central pocket present, but is invisible from the ventral view; two small and rounded copulatory orifices are widely separated, facing laterad; the spermathecae are two-chambered, with short insemination ducts.

DISTRIBUTION. The type locality only: Malaysia, Mt. Kinabalu National Park (Map).

\section{Uroballus kinabalu sp.n.}

Figs 6-10, Map.

TYPE: Holotype 9 (NBCL, RNMH.ARA.17920) from [Malaysia, Sabah], North Borneo, Mt. Kinabalu N[ational] P[ark], Poring Hot Springs $\left(6^{\circ} 2^{\prime} \mathrm{N}, 116^{\circ} 50^{\prime} \mathrm{E}\right), 500-700 \mathrm{~m}$ a.s.1., primary forest, canopy fogging Xanthophylum affine (Polygalacea), 21.04-12.05. 1992, A. Floren. Ex. coll. C.L. Deeleman-Reinhold.

ETYMOLOGY. The specific epithet is a noun in apposition related to the type locality, Mt. Kinabalu N.P. in North Borneo.

DIAGNOSIS. Of the illustrated Uroballus females [Prószyński 1987: 108; Żabka, 1985: fig. 638; Logunov, 2014: figs 1-10], the new species is closest to U. koponeni Logunov, 2014, from which it can be easily distinguished by different relative sizes and conformation of the spermathecal chambers (Fig. 10), the shorter spinnerets and the absence of long abdominal hairs (Fig. 7).

DESCRIPTION. Male unknown.

Female. Measurements. Carapace 1.53 long, 1.03 wide and 0.50 high at PLE. Ocular area 0.85 long, 0.98 wide anteriorly and 1.00 wide posteriorly. Diameter of AME 0.33. Clypeus not marked, chelicera length 0.30. Abdomen 1.65 long, 0.93 wide. Length of leg segments: I: $0.65+0.40+0.33+0.28+0.25$ (1.91); II: $0.53+0.30+0.28+0.25+0.25(1.61)$; III: $0.48+$ $0.23+0.25+0.25+0.28$ (1.49); IV: $0.65+0.31+$ $0.35+0.30+0.29$ (1.90). Leg formula: I,IV,II,III. Leg spination. Leg I: Tb v 1-2-2ap; Mt v 2-2ap. Leg II: Tb v 0-1-0; Mt pr 1-1ap. Legs III and IV: without visible spines. Coloration (in alcohol). Carapace light yellowish brown, its surface shagreen, with dark brown around eyes; carapace covered with white recumbent scales and long white hairs on thorax; fovea very small, poorly visible. Clypeus is not marked. Sternum yellow in the centre and brownish yellow on its margins. Endites, labium and chelicerae yellow, tinged with brown (Fig. $6)$. Abdomen light yellow; dorsum with a pattern of 4 5 transverse pale brownish stripes (Fig. 7); sides with short longitudinal brownish lines. Book lung covers light yellow. Spinnerets long, light yellow, but tinged with grey. Legs I and II light yellow, with dark brown spots on distal ends of $\mathrm{Pt}, \mathrm{Tb}$ and $\mathrm{Mt}$; Fm I slightly swollen. Legs III and IV light yellow, with dark brown rings at segment joints. Palps light yellow, with long and dense white hairs on median-dorsal sides of their tarsi. Epigyne and spermathecae as in Figs 9, 10: a short, narrow central pocket is present; two small and rounded copulatory orifices are widely separated, facing each other; the spermathecae are two-chambered, with short insemination ducts.

DISTRIBUTION. The type locality only: Malaysia, Mt. Kinabalu National Park (Map).

\section{Acknowledgements}

I wish to sincerely thank Christa Deeleman-Reihnhold and Karen van Dorp for giving access to the Salticidae material retained at the Naturalis Biodiversity Center (Leiden, The Netherland).

\section{References}

Logunov D.V. 2014. Description of a new species of Uroballus Simon, 1902 (Araneae: Salticidae) from Malaysia, with the longest spinnerets of any known jumping spider // Zootaxa. Vol.3894. No.1. P.183-187; doi:10.11646/zootaxa.3894.1.16

Logunov D.V., Ikeda H., Ono H. 1997. Jumping spiders of the genera Harmochirus, Bianor and Stertinius (Araneae, Salticidae) from Japan // Bulletin of the National Museum of Nature and Science Tokyo. Ser.A. Vol.23. No.1. P.1-16.

Maddison W.P. 2015. A phylogenetic classification of jumping spiders (Araneae: Salticidae) // Journal of Arachnology. Vol.43. No.3. P.231-292; doi: http://dx.doi.org/10.1636/arac-43-03231-292

Ono H. 1988. A revisional study of the spider family Thomisidae (Arachnida, Araneae) of Japan. Tokyo: National Science Museum. ii $+252 \mathrm{pp}$.

Prószyński J. 1987. Atlas rysunków diagnostycznych mniiej znanych 
Salticidae 2. Siedlce: Zeszyty Naukowe WSRP. 172 pp.

Simon E. 1903. Histoire naturelle des araignées. Paris. T.2. P.6691080.

WSC 2017. World Spider Catalog. Natural History Museum Bern, online at: http://wsc.nmbe.ch, version 18.5 (accessed on December 24th, 2017).

Żabka M. 1985. Systematic and zoogeographic study on the family
Salticidae (Araneae) from Viet-Nam // Annales Zoologici, Polska Academia Nauk. Vol.39. No.11. P.197-485.

Responsible editor K.G. Mikhailov 